\title{
自然と共生する流域圏·都市再生シナリオ に関する流域圏的考察
}

過去約 100 年間に急増した人口が今後減少に向かう日本では, 流域・流域圈というス ケールにおいて, 喪失した水物質循環や生態系, 景観を復元しながら, 自然共生型の持 続可能な発展を目指すことが求められる. 本論文では流域・流域圈の捉え方について整 理するとともに, その再生シナリオの必要性について述べた. また国内外の先進的な実 践事例・計画をその流域圏の形態・スケールとの係わり，再生・形成目標から分析し， それらを考慮した上で自然と共生する流域圏・都市再生シナリオのモデルを提示した.

【キーワード】自然共生型流域圈・都市、再生シナリオ

\section{1. はじめに}

わが国では、稲作が伝播して以来、長い間、河川 流域（水系）を基盤として社会が発展してきた。こ の百年の人口の増加、経済発展とともに流域圈の都 市化が進み、都市の存立基盤である流域圈の環境に 大きな負荷をかけてきた。特に 20 世紀の後半の都 市化は急激で、環境への負荷は大きく、21世紀には 負の遺産を解消し、自然と共生する流域圈・都市の 再生が求められている。

本論文では、流域圈についての概念の整理を行う とともに、20世紀の人口増加、経済発展と都市化が 流域圈・都市に与えた環境負荷を流域論的な視点か ら明らかにした。そして、自然と共生する流域圏・ 都市の再生について、その先進的・実践的な事例を 取り上げて分析するとともに、再生シナリオを設 計・提示した。

\section{2. 従来の研究と本研究の基本的立場}

人口増加、経済発展と都市化が流域圈の環境に与 えた影響の把握と流域圈・都市の再生シナリオにつ いての系統的な研究は、総合科学技術会議が第 2 期 科学技術基本計画の中で重点研究に設定した「自然 共生型流域圈・都市再生イニシャティブ」研究報告 書にみることができる ${ }^{1)}$ 。そこでは、流域圏の環境 *1 社会交通工学科 $047-469-5228$

yoshikawa@trpt.cst.nihon-u.ac.jp
（1)水・物質循環、(2)生態系）モニタリング、流域 圏の環境のモデリング、個々の環境再生技術の研究 がなされている。そして、自然と共生する流域圈・ 都市への再生シナリオについては、開発したモデル を用いた解析のために設定したプリミティブなもの が報告されている。すなわち、国立環境研究所の研 究では、地球温暖化研究における代替シナリオ (SERES シナリオ ${ }^{2)}$ に類似した極めて単純化したシ ナリオを設定しており、問題の定性的な分析をおこ なっている。国土技術政策総合研究所の研究では、 湖沼の水質改善についての代替的な対応案を設定し、 いわゆる個々の施策の感度分析を行っている。また、 同時期に行われた再生シナリオに関連した研究とし ては盛岡らによるものがあり、シナリオ設計システ ムに関するものやそれを支援する地理情報システム に関する研究が行われている ${ }^{3), 4)}$

これらの研究における流域圈・都市再生シナリオ は、作成したモデルを用いた検討のためのシナリオ、 あるいはシナリオ設定の支援に係わるものであり、 現実の問題を解決していくための実践的な再生シナ リオとはなっていない。

社会問題への対応施策や再生シナリオの研究につ いてふり返ってみると、現代社会を延長した場合の 資源制約や環境問題を明示するために、社会の因果 システムを内在させてシステム・ダイナミックスと いう手法で評価したローマクラブの分析 ${ }^{5)}$ があった。 
その後、アメリカで始まった方法であるが、環境政 策の決定に際して施策の代替案を設定してその効果 等を比較・検討することが行われるようになった。 この代替案を設定して問題を分析しつつ施策や再生 シナリオを検討する方法は、20世紀後半を通じて現 在まで多くの研究者により用いられる手法となって きた ${ }^{6)}$ 。しかし、この代替案を並べて比較する手法 は、研究面や問題点の分析の局面では数多く用いら れてきたが、実践的な施策や再生シナリオの設計・ 提示という面ではあまり用いられていない。

具体的な行動につながる実践的な対応施策や再生 シナリオについての研究としては、内外の萌芽的・ 先進的な実践事例を分析し、それを踏まえた提案を 行っているものとして、吉川によるものがある7),8)。 そこでは、基本的な施策の方向を定めつつ、個々の 施策についてそれを取り巻く制約条件と可能性を分 析し、少し高めの目標を設定することにより、流域 圈・都市の再生シナリオ（再生や健全化に向けての 具体的な対応・行動計画）の設計、設定を行ってい ることが知られている。

本論文では、自然と共生する都市・流域圈の再生 シナリオについて、近年の都市化等が流域圈・都市 に与えた影響を把握するとともに、具体的な実践に つながるシナリオを設計・提示することを目指し、 具体的な事例を分析しつつ、これからの時代の再生 シナリオの提案を行った。流域および流域圈の視点 を明確にするとともに具体的な実践につながる再生 シナリオを設計・提示したことが本論文の新規性と 特徴であると考えている。

\section{3. 流域、流域圈のとらえ方}

本論文では、自然と共生する流域圏・都市の再生 を議論するため、ここではその前提となる流域、そ して流域圈について、整理しておきたい。

日本では、稲作の伝来以来、当初は小河川の汇濫 原での農耕から始まり、戦国時代から江戸時代初期 に大河川の汇濫原を新田として開発し、水系に依存 して社会が発展してきた。この時代は、ほぼ農耕面 積に比例して人口が増加した時代であった ${ }^{7}$ (図-1)。 江戸時代はもとより、戦後も 1960 年代頃までは、 水田での稲作、さらには里山や奥山の森林と密接に 関連する水の流れや、木材や肥料としての草木の

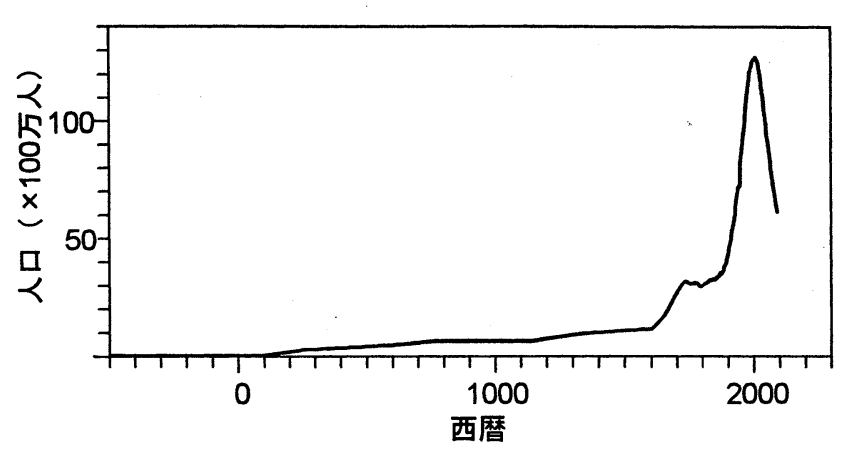

図-1日本のこの 2000 年の人口増加

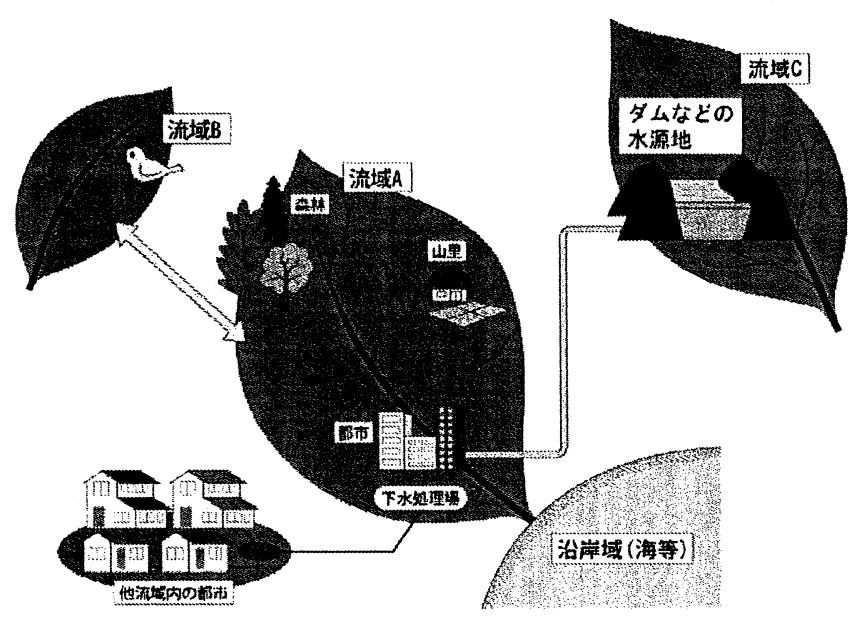

図-2 一般的な流域と流域圈のイメージ

物質移動、薪炭林によるエネルギーの流れ等、流域・ 水系との関わりが濃厚に感じられる、いわゆる流域 圈といえる地域社会が成立していた。その後、エネ ルギーの転換（薪炭から水力、石炭、石油等）、鉄道 から始まり道路、航空という交通・移動手段の発展 等により、水系や流域圈を越えた社会経済活動が行 われるようになった。そして、経済と国土、都市化 と国土が議論される時代が長く続いてきた。

しかし、人口が安定し、減少するこれからの時代 の地域社会や国土の計画・経営、人々の暮らしや地 域社会の経営や再生は、自然と共生する社会の再生 といった視点から、再び流域圈に立脚することが求 められる時代となった。

これらのことを踏まえて、以下では本論文で議論 する際の流域圈とは何かについて明確にしたい。

\section{(1)流域、流域圈のとらえ方}

流域、あるいは流域圈のとらえ方としては、以下 のようなものが挙げられる。

(1)水や水を媒介とした物質の移動（水・物質循環） からみた場合 
表-1 流域圈の圈域についての多角的な視点

\begin{tabular}{|c|c|c|}
\hline 観点 & 圈域 & 領域、内容 \\
\hline \multirow{9}{*}{ 水・物質循環系の観点 } & 集水域＝流域 & 表面流が集まる領域（集水域）をいう。 \\
\hline & 氾濫域 & 洪水の際に氾濫水が及ぶ領域または及ぶと想定される領域をいう。 \\
\hline & 利水域 & $\begin{array}{l}\text { 利用する水を他の流域から運んでくる場合はその水が集められる領域も含め } \\
\text { て、水を利用に関わる領域をいう。 }\end{array}$ \\
\hline & 灌溉域 & 灌溉のために水を運んでいる領域をいう。 \\
\hline & 排水域 & $\begin{array}{l}\text { 利用した水・利用後処理した水を排水する領域をいう。排水する先が他流域 } \\
\text { や海などの場合、そこも含まれる。 }\end{array}$ \\
\hline & 沿岸域 & $\begin{array}{l}\text { 利用後の水を排水する領域、あるいは土砂が流れにより移動し堆積する領域 } \\
\text { をいう。 }\end{array}$ \\
\hline & 下水道域 & 下水道で水が流れる領域をいう。 \\
\hline & 地下水域 & 地下水の流れる領域をいう。 \\
\hline & 総合的な水循環から見た流域圈 & $\begin{array}{l}\text { 上述した水が移動する領域のすべて、あるいはいくつかの領域を含んだ領域 } \\
\text { をいう。 }\end{array}$ \\
\hline 生態系の観点 & $\begin{array}{l}\text { 生態系の空間的な広がりに対応した表 } \\
\text { 面流が集まる集水域（流域） }\end{array}$ & $\begin{array}{l}\text { 生態系の空間的な広がりは、しばしば恣意的に限定される必要がある。表面 } \\
\text { 流が集まる集水域（流域）は地形的にわかりやすく、河川を軸とした物質流 } \\
\text { 動の構造を持つため、生態系の諸要素を総合的に把握しやすい。 }\end{array}$ \\
\hline \multirow[b]{3}{*}{$\begin{array}{l}\text { 経済圈・文化圈・生活 } \\
\text { 圈 }\end{array}$} & $\begin{array}{l}\text { 地図の基本単位としての表流水が集ま } \\
\text { る集水域 }\end{array}$ & $\begin{array}{l}\text { 流域を入れ子状に分割していくことで行政的な区分に代わり国土を分割でき } \\
\text { る。の流域を地図の基本単位とする考え方は流域住民に自然との共生を促 } \\
\text { す感覚をもたらす。 }\end{array}$ \\
\hline & 舟運等を通じて人間活動の及ぶ領域 & 舟運等により人間が移動する範囲を経流圈・文化圈としての流域圈とする。 \\
\hline & 第三次全国総合開発計画でいう流域圈 & 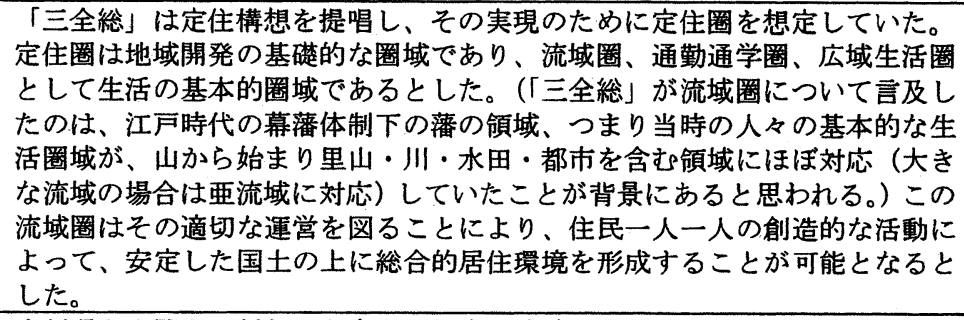 \\
\hline 総合的な流域圈 & 鶴見川水マスタープランでいう流域圈 & $\begin{array}{l}\text { 水循環と人間との係わりを考えた場合、流域および関連する分水界を越えた } \\
\text { 水利用域や排域、また生態系の空間的な広がりなと含む流域圈を捉える。 }\end{array}$ \\
\hline
\end{tabular}

流域の基本的なイメージを図-2 に示した。流域は 川の支流からなるいくつかの支流域（あるいは亜流 域）を包含するものである。その支流域の中で、さ らにその支流に対応した支流域をもち、流域はいわ ゆる入れ子構造となっている。

\section{○流域に関わる圈域}

水・物質循環の視点からは、流域に関わるものと して、表-1 に示すようないくつかの圈域がある。 ○その実例

上記の圏域について、そのいくつかの実例をみて おきたい。

まずは流域、すなわち集水域である。日本最大の 流域である利根川流域を図-3に示す。元々は東京湾 に流入していた利根川は、江戸時代に大きな改変が 行われ、東を流れていた鬼怒川の下流域に流入する

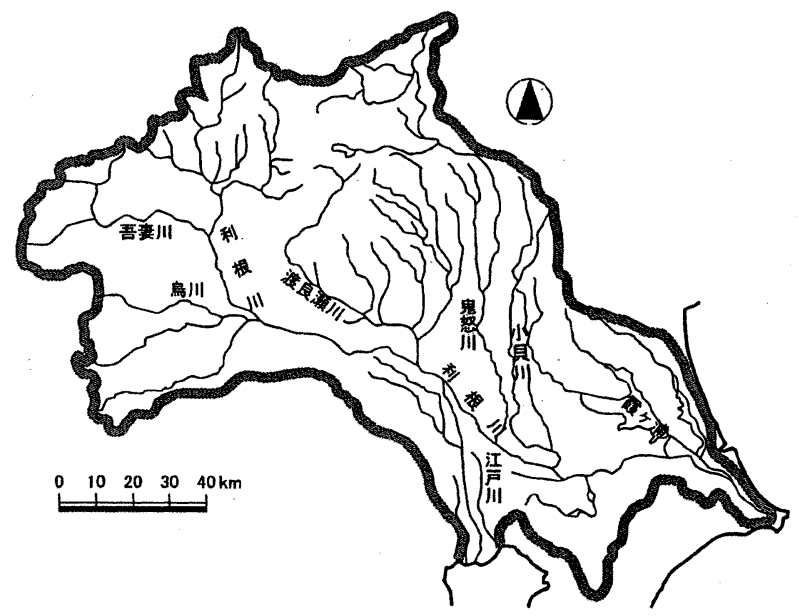

図-3 利根川流域 ${ }^{10)}$

ように東に付け替えられた。利根川は鬼怒川と一体 となって千葉県の銚子で太平洋に流入する河川とな 


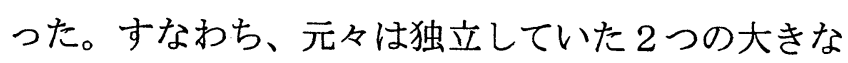
流域が人工的に一つとなった ${ }^{7}$ 。図-3より、大きな 流域やその支流域がイメージされよう。図-4 は、首 都圈という巨大都市にある都市化流域として、丘陵 地を流れる鶴見川流域と低平地を流れる中川・綾瀬 川流域（かつての利根川、荒川の氾濫原を中心とし た流域）を示したものである。この図より、丘陵地 や低平地を流れる中規模の河川流域がイメージでき よう。図-5 は首都圏を構成する主要な大規模、中規 模河川の流域を示したものである。

図-6 は、東京という大都市の利水域を示したもの である。東京は、東京を流れる多摩川と荒川から取 水した水に加えて、図の上方の利根川、左の方の相 模川から水を導水して利用している。東京は、流域 外に依存して利水を行っていることが知られる。

利用された水の排水域（その一部は下水道域）を 東京についてみたものが、図-7である。図中の下は、 都心で比較的早くから下水道の整備が行われ、その 延長上で現在の下水道の排水域（公共下水道域）が できている区域のものである。図中の上は東京の郊 外における下水道の排水区域を示しており、広域を カバーする流域下水道域を示している。いずれの下 水道域も、多くの場合は重力による污水の流下が行 われており、河川の流域あるいはその支流域にほぼ 対応している。

図-8 は河川の汇濫域（汇濫原）について、関東の 場合をみたものである。関東の主要な河川による氾 濫原が示されている。この汇濫域は、河川の汇濫に より浸水する可能性がある地域である。前述の中 川・綾瀬川流域 (図-4 参照) の大半は、利根川およ び荒川の氾濫原であることが知られる。

図-9 は地下水 (浅層地下水) の流れのイメージ図 である ${ }^{10)}$ 。丘陵や山地等での雨水の地下浸透、水田 や河川などからの地下浸透、そして河川への地下水 の流出など、地表面や河川との水のやりとりがある 浅い層の地下水の流れを示している。また、地下水 としては、深い層（地下水盆）があり、都市での地 下水の汲み上げにより、深い層の地下水の層が圧密 沈下して地盤沈下が生じる。地盤沈下は、深層地下 水層の存在を示している。

(2)生態系からみた場合

生態系の広がりを把握する視点として、岸は、生

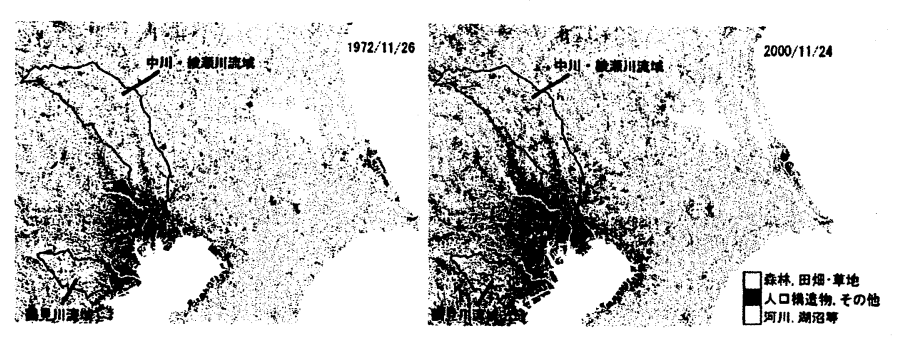

図-4 関東平野における都市化の進展と中川 - 綾瀬 川流域、鶴見川流域 (LANDSAT のデータから作成)

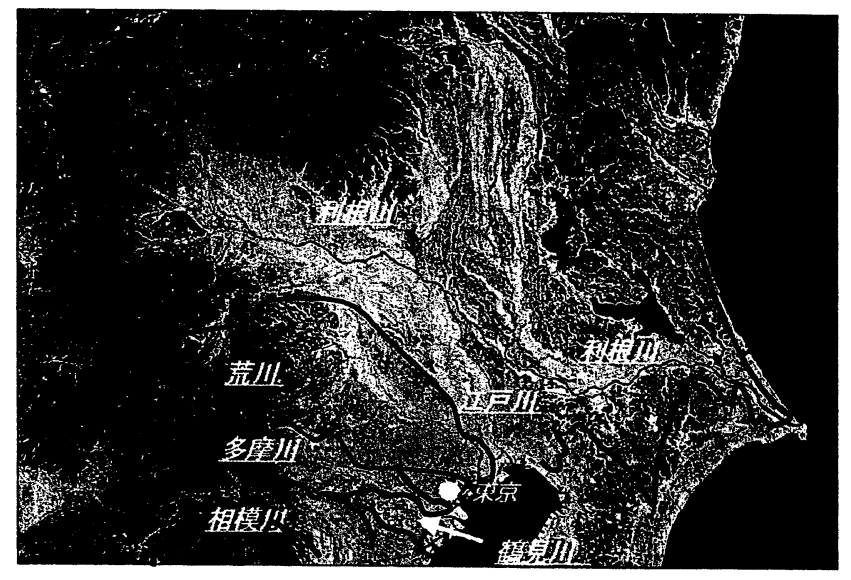

図-5 首都圈を流れる大河川の流域 (LANDSAT のデ 一タから作成)

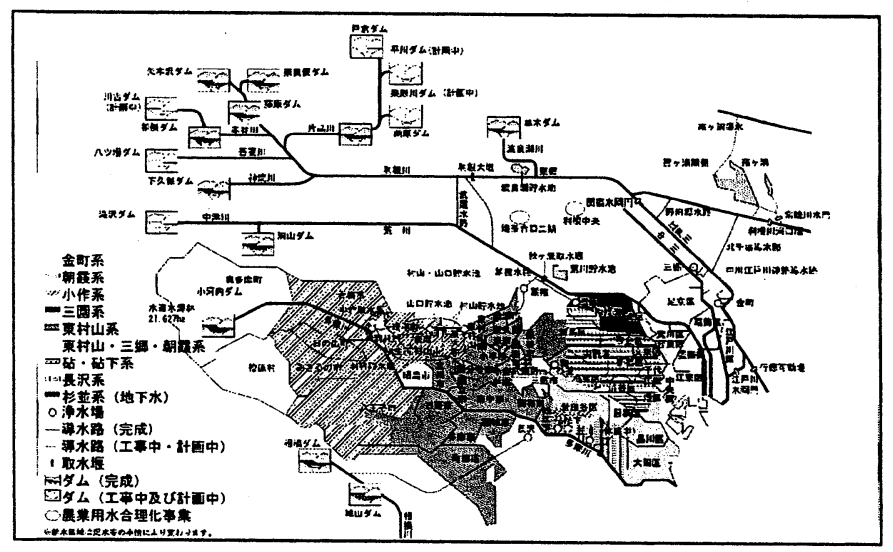

図-6 利水域のイメージ（東京都上水道域。東京都 資料を参考に作成)

態系を総合的に把握するためには、表流水が集まる 集水域が地形的に分かりやすく、河川を軸とした物 質流動の構造をもつため、生態系の諸要素を把握す る上でも適当であるとしている (表-1 参照) ${ }^{11)}$ 。水 生あるいは水際の生態系は水系に密接に関係し、陸 域の生態系も奥山、里山、水田、畑地、沿岸域など の河川流域の地形や地質に密接に関係していること から、流域、すなわち集水域が生態系の諸要素を把 握する上での重要な広域生態複合の基盤（ランドス ケープ) である。 

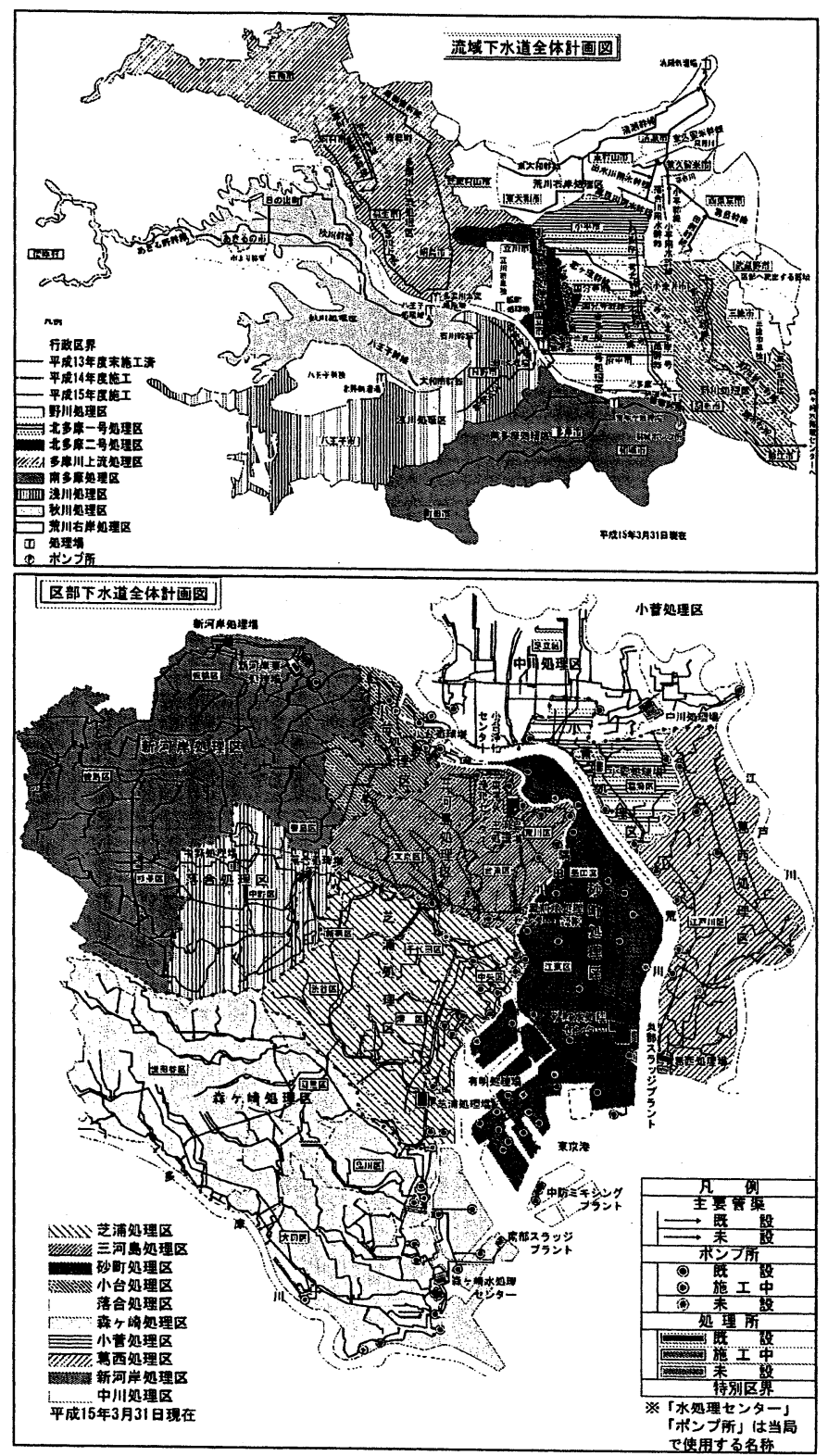

図-7 抹水域のイメージ（東京都区部、流域下水道 全体計画図。東京都資料を参考に作成)

鶴見川流域では、生物多様性の保持や水と緑のネ ットワーク形成の視点から、流域（支流域）に対応 したものとして、図-10 のようなものを示している 12)。

\section{(3)経済圏・文化圏・生活圏}

この観点からの圈域としては、表-1（前出）に示 したようなものがある。それらの中で、第三次全国 総合開発計画 (三全総) で提唱された、いわゆる流 域圏構想が注目されてよい ${ }^{13)}$ 。そこでは、明確な流 域圏の定義は行われていないが、その構想は概ね以 下のようなものであり、ある程度まとまりのある流 域（大河川では支流域）がその圈域として想定され ていた。

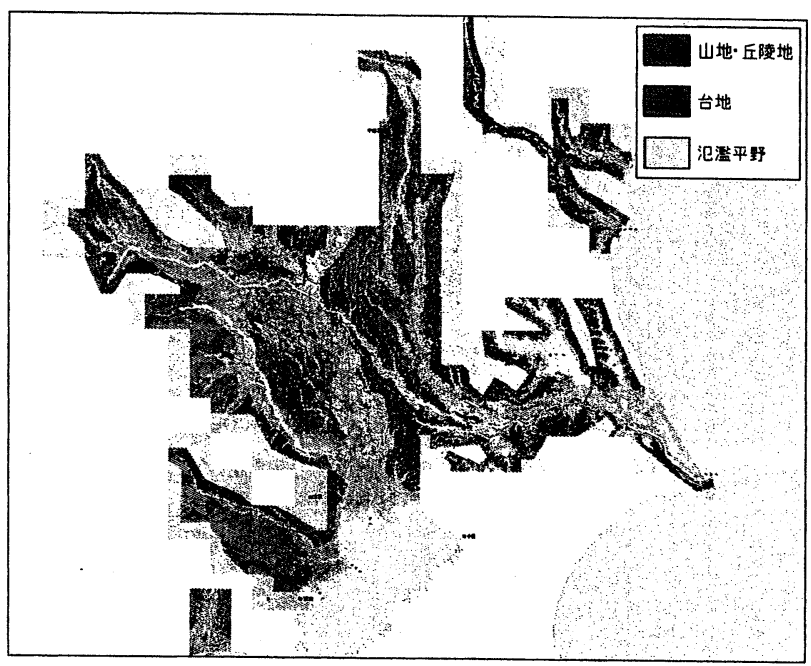

図-8 氾監域（関東。国土地理院地形分類図をもと に作成)

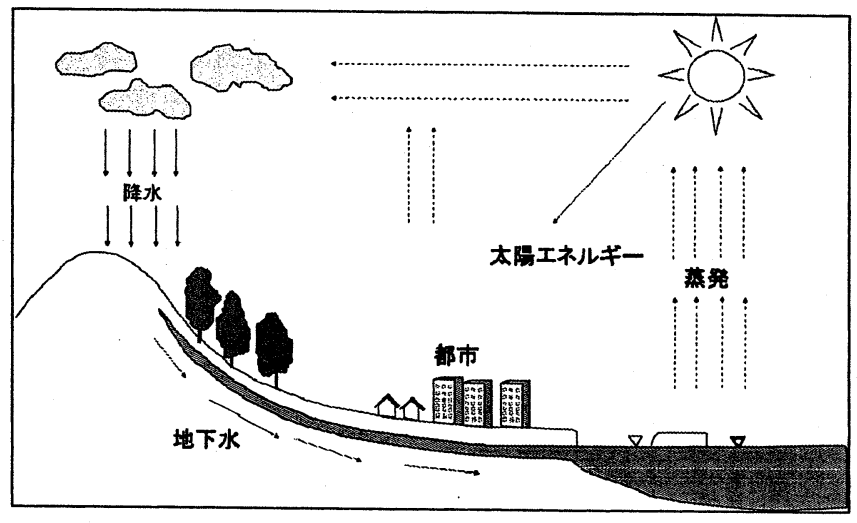

図-9 地下水域 ${ }^{10)}$

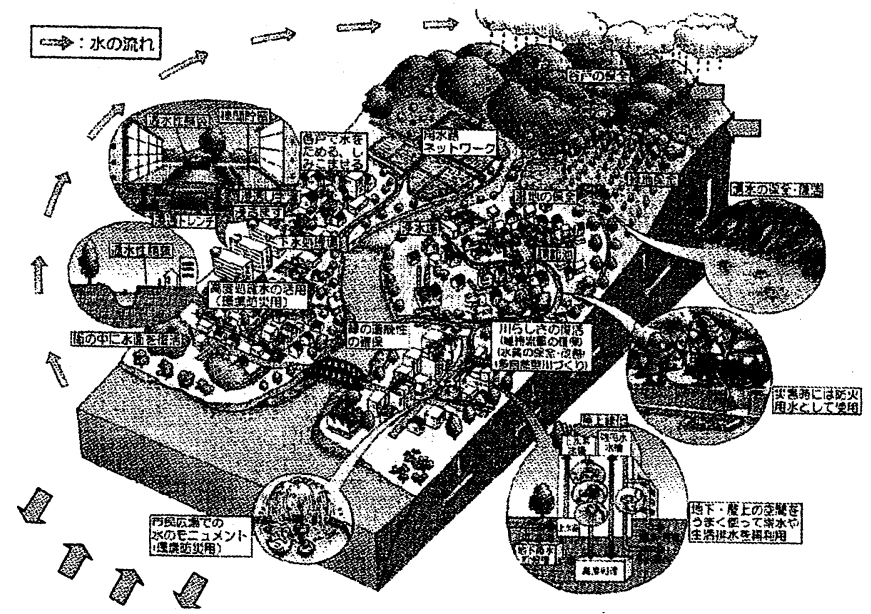

図-10 生態系と流域地形との対応 (鶴見川流域) ${ }^{12)}$

第三次全国総合開発計画（三全総）では、その基 本理念として定住圈構想を提示した。そこでは、人 間居住の総合的環境の形成を図るという方式（定住 構想）を選択するとし、人間居住の総合的環境とし ては自然環境、生活環境、生産環境が調和したもの でなければならないとしている。そして、定住圏は 
地域開発の基礎的な圈域であり、流域圈、通勤通学 圏、広域生活圏として生活の基本圏域であり、その 適切な運営を図ることで、住民のひとり一人の創造 的な活動によって、安定した国土の上に総合的居住 環境を形成することができるとしていた。

三全総における水系の総合的管理の項では、水系 の森林、水田、ため池等の土地利用の転換による水 害の問題、自然環境の容量の低下、水循環系の短絡 化による河川流量の減少や河道の単調な人工水路化 等による陸水環境の悪化、瀬と淵等の川のもつ独特 の自然環境が消滅し、多様な陸水生態系が貧困化し たこと等、今日を見通した指摘をし、水系ごとに、 その流域特性に基づいて流域の土地利用の可能性と 限界を求めつつ、流域の適正な開発と保全の誘導を 図るとしている。この他にも、その後の総合的な治 水や多自然型の川づくり、瀬と淵からなる多様な陸 水生態系の維持、流域全体での水循環システムのあ り方等の将来を見通した提言がなされている。

すなわち、大都市圏流域については、災害の観点 からの土地利用・構造物の誘導・規制といった総合 的な治水対策や悪化した陸水環境のための水質対策 を、流域を系として総合的に実施すること、そのた めに都市的開発等について、抑制の観点からその適 正を図ること等を示している。小流域では、自然の 容量が小さいことから国土の保全と利用に特に細か い配慮が必要であること、さらに土地利用の要請か ら画一的、単調な断面の水路になりやすく、瀬と淵 を有する陸水環境が損なわれ、貴重な都市域の自然 環境・生活環境空間が喪失されることから、それら に十分配慮する必要があるとしている。湖沼等の閉 鎖性水域を有する流域では、排水規制、下水道整備 とあわせて、湖沼の集水流域内の適正な土地利用、 人口・産業の配置に努めるとしている。

この計画 (三全総) が策定されたのは経済の高度 成長の真只中であったが、その時代を背景としつつ も、今日でも通用する思想や構想が示されている。

この構想の際に、全国は 200〜300 の定住圈、流域 圏としては約 230 流域の圈域が想定されていたとい う。この圈域数は幕藩体制下での藩の数 (270 程度) に近いものである。

しかし、この構想は、矢作川流域や五ヶ瀬川上流 での一部の活動を除き、ほとんど実現することが

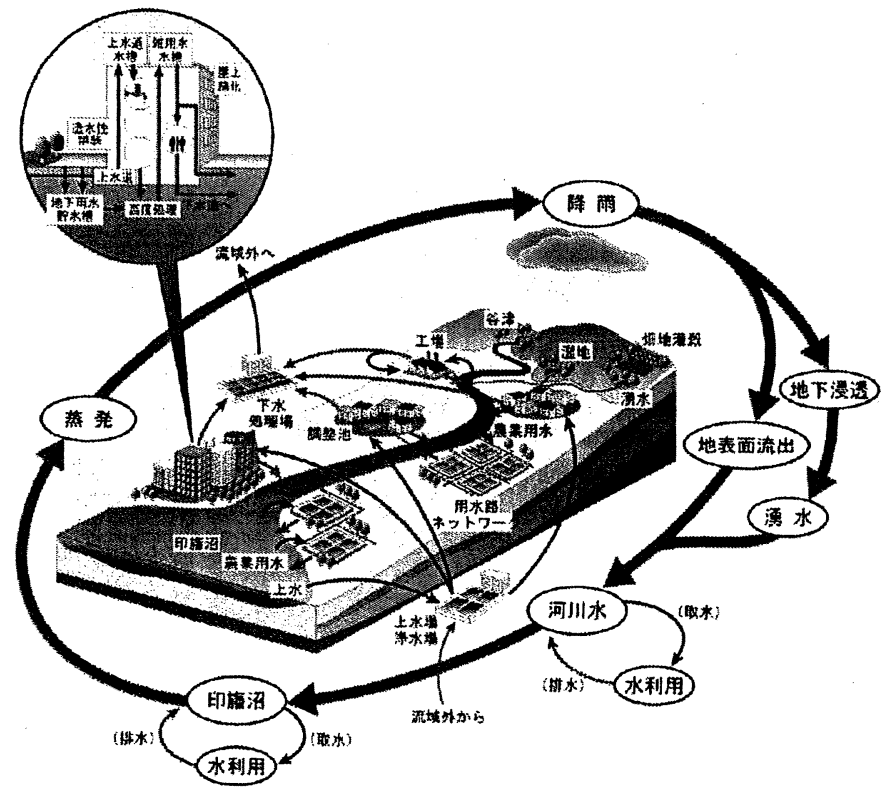

図-11 水循環の健全化が議論されている印旜沼流 域の流域圈 ${ }^{14)}$

なかった

そして、時代を経て、21 世紀の国土のグランドデザ イン（五全総）で下河辺淳らにより再び新しい時代 の流域圈の議論がなされた ${ }^{14)}$ 。人の移動が激しくな った現在では、都市と自然、暮らしと自然を考える にあたって、住むということ（定住）の概念も、そ の地で一生住むというのではなく、住む時間は短く なっていることも認識して定住圈・流域圈を考えて 行く必要がある ${ }^{8)}$ 。

(4)総合的な視点からみた場合

水・物質循環の視点に加えて、流域内での生物多 様性の保全、水と緑のネットワークづくり等を総合 的に考慮した場合の流域のイメージを鶴見川流域を 例に図-10 (前出) に示した。そこでは、表-1 に示 した総合的な流域圈という視点がとられている。 人々の生活や経済活動との関わりから流域圈を捉え る場合、都市域では、このような総合的な流域圈と いうことになる。

同様に、水循環系を中心とした再生が議論されて いる印旛沼・流域では、図-11 に示したような流域 圈のとらえ方が行われている ${ }^{14)}$

\section{(2)本論文での取り扱い}

上述した流域、流域圈に関わることを考慮しつつ、 本論文で議論する自然と共生する流域圈・都市再生 シナリオの考察では、流域圏を以下のように定義を する。 
地表面の水が流れて集まる区域を流域といい、水 文学では集水域ともいう。既に述べたように、水・ 物質循環の観点からは、表流水の集まる流域という エリアに加えて、洪水の汇濫する可能性のある区域 を示す汇濫域、水利用の形態からみて他の流域から 水を導水している場合にはその水が集められる流域 も含めた利水域、利用した後の水の排水に着目した ときのその元の水利用区域を含めた排水域、さらに は地下水の流れに着目した地下水域がある。このよ うな水循環の観点からは、それらの全て、またはそ のいくつかを含めた範囲を流域圈と見ることもでき るが、それはあくまでも水・物質循環的な見方であ る。

流域は、表流水の流れとともに、その地域のラン ドスケープを形作っている。そして、奥山、里山、 水田、都市、海に至る区域を包含した流域では、自 然の状態ではそのランドスケープに対応した生態系 があり、人々の暮らしと経済活動があった。現在で は人間活動の影響を大きく受けているが、その人工 的な作用のもとでも、表流水の流域ランドスケープ に対応した水の流れと生態系が残されている。

三全総で提唱された流域圈といった場合は、かつ て自然の流域のランドスケープに対応した人々の暮 らしと活動があり、それに対応した見事な水系社会 が成立していた歴史から、この場合には、表流水の 流域を流域圈とみているといってよい。

水・物質循環や生態系、基礎的な人々の暮らしや 生産活動と比較的よく対応し、自然と共生する流域 圈・都市の再生計画づくりや実践の単位として分か りやすいことから、本論文では、流域圈を表流水の 流域に対応させて議論を進める。

自然と共生する流域圈・都市再生シナリオ検討の 対象として、例えば首都圈や東京湾とそこへの流入 河川流域といった広域を扱う場合には、複数の流域 圏をたばねたものとなる。その例として、東京湾に 直接流入する複数の河川流域を図-12 に、首都圈を 包含する流域圈 (主要河川流域)を図-13に示した。

\section{4. 人口増加と都市化が流域圈に与えた影響}

人口増加と都市化が流域圈に与えた影響が最も大 きかったといえる日本の首都圈を例にとりあげる 7), 8)。

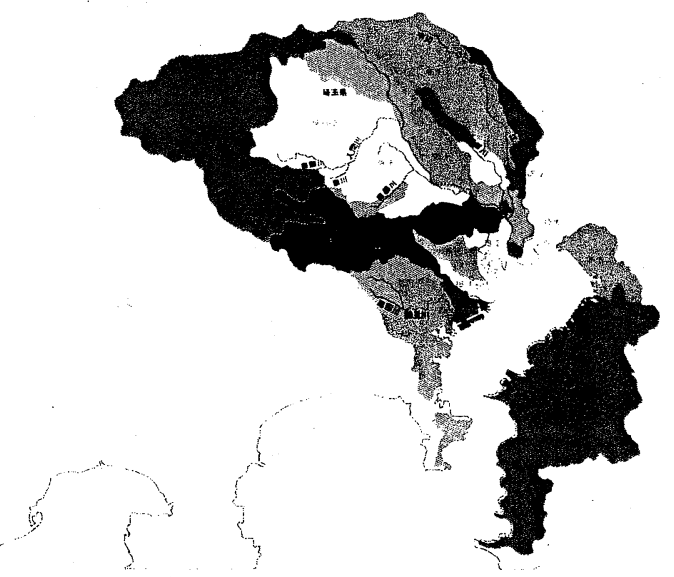

図-12 東京湾と東京湾流入河川流域（国土交通省 流域下水道資料より作成)

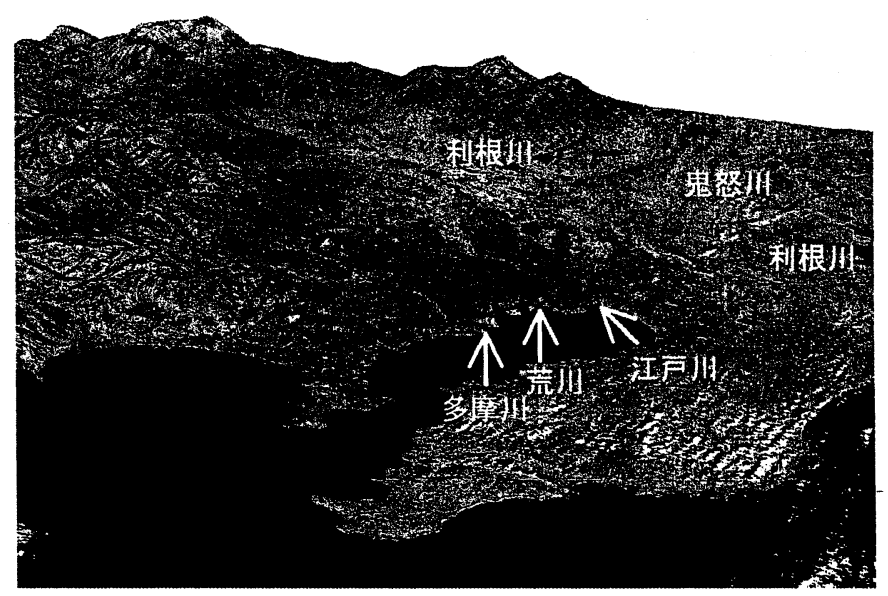

図-13 首都圈を包含する流域（主要河川。LANDSAT のデータより作成)

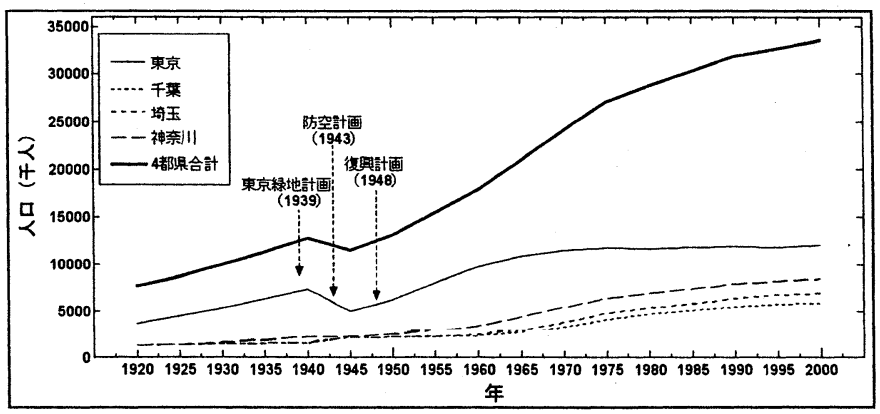

図-14この百年の首都圈の人口増加（厚生労働省 統計要覧等より作成)

この首都圏についてみると、この百年の人口の 増加は図-14 に示すようであった。このような人口 増加に伴った都市化の進展の様子を示したものが前 記の図-4である。そして、このような人口増加、都 市化の進展とともに、この地域にあった河川や農業 用水路等は図-15 に示すように消失した。図-16に 示したように、東京湾においては埋め立てが進み、 
干潟や藻場などが消失し、海岸線には直立の企業岸 壁が出現し、市民の海へのパブリックアクセスが不 可能な場所が大半となった。

河川や湾域等の閉鎖性水域の水質は図-17 に示す ように推移した。河川についてみると、現在は多く の河川で水質基準を満たすまで水質は改善されてき ている。河川の水量については、下水道で水が川を バイパスする都市河川や、農業や都市用水の取水が 行われる堰の下流では大幅に水量が減少した。

さらに、都市域における典型的な河川空間の問題 として、高速道路に上空を覆われた日本橋川や渋谷 川といった問題がある（写真-1）。この問題は、日 本橋川が江戸・東京の発祥の地でもあり、政治的に も 20 世紀に形成された負の遺産解消の対象とされ る典型的な事例でもあることから、近年さらに注目 されるようになった。他にも多くの都市の河川おい ても、丘陵地の多くの都市河川は深く掘り込まれた 川となり、川へのパブリックアクセスも困難な川が 多くなった（写真-2）。また、低平地の川では川岸 に堤防が設けられ、川とまちとが分断された（写真 $-3)$ 。

このような水域への環境の負荷に加えて、市街化 とともに水域と等価ともいえる都市の緑の䙵失によ り、都市の環境は大幅に悪化したといえる(写真-4)。

以上のように、流域の都市化の急激な進展により、 水域、陸域の生態系も大きく消失あるいは貧弱化し た。さらに重要な問題として、都市に住む人々と自 然との係わりの機会の消失と、それに伴った自然一 の意識の喪失が生じた ${ }^{8), 11) 。 ~}$

\section{5. 先進的な実践事例と流域圈·都市再生シナリオ の比較分析}

ここでは、自然と共生する流域圈・都市再生シナ リオの設計、提示に資するため、その萌芽的、先進 的な取り組みがなされている国内外の事例をとり上 げて分析した。対象とした実践事例の主要なものを、 表-2に示した。

これらの事例は、流域スケールで既にある程度長 期にわたって取り組みが行われてその実績があるも の、あるいは当初の事業が遂行され、社会的な側面 から注目に值するものなどである。都市化の急激な 進展に対して、自然との共生を目指した実践事例と

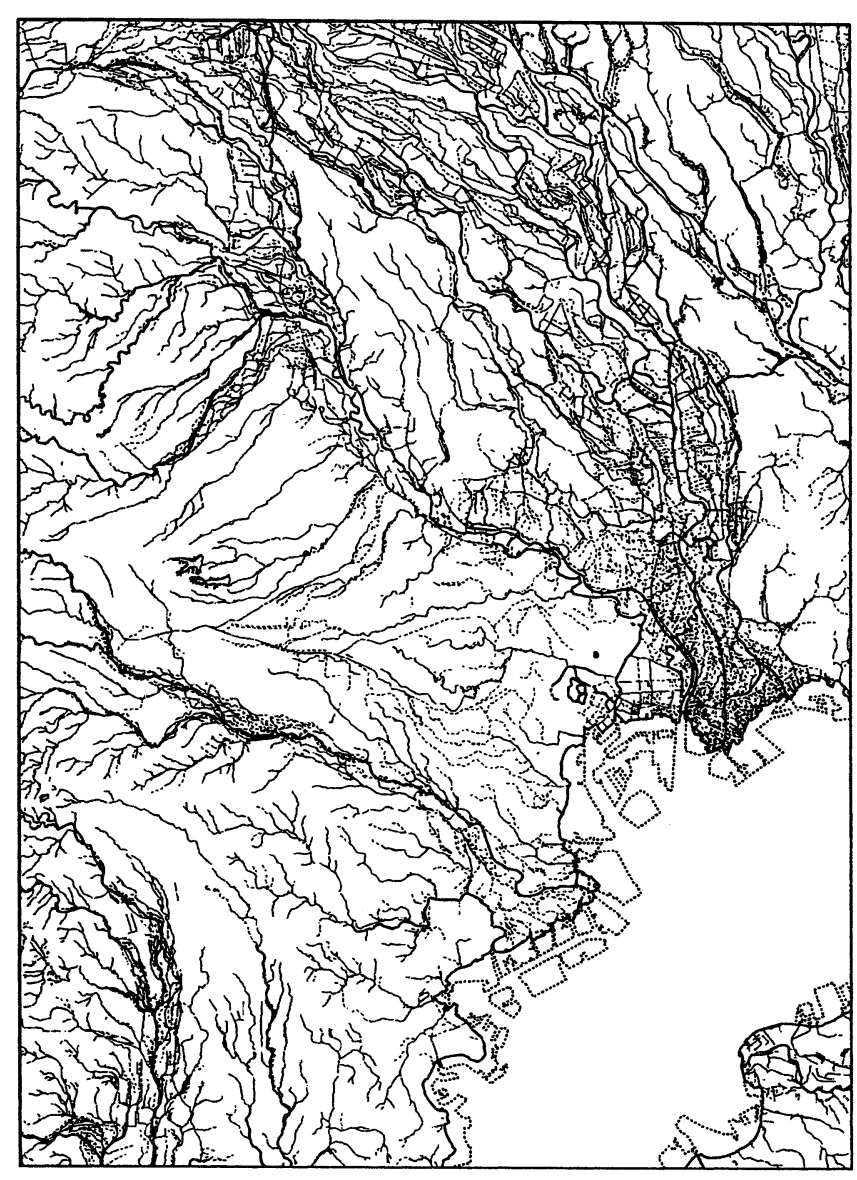

図-15 河川 - 水路網の消失 （点線は明治 40 年頃には存在し，現在は消失した 河川 - 水路網。国土地理院土地利用図より作成)

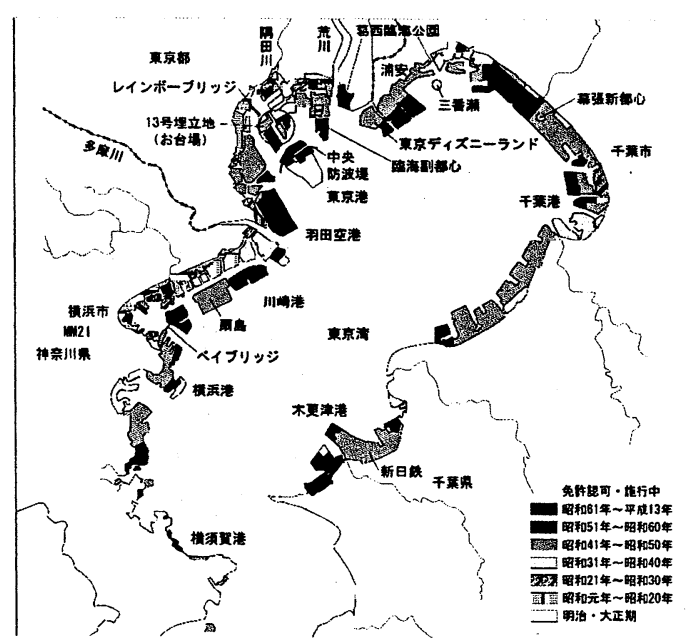

図-16 東京湾岸の埋め立て（千葉県企業庁資料よ り作成)

しては、表には記載していないが、洪水という厳し い自然との共生（人間には都合が悪い洪水という自 然との共生の問題。水循環に係わる問題）があり、 日本やタイ国の首都圈域において実践された総合的 治水の実践事例もある ${ }^{9)}$ 。 


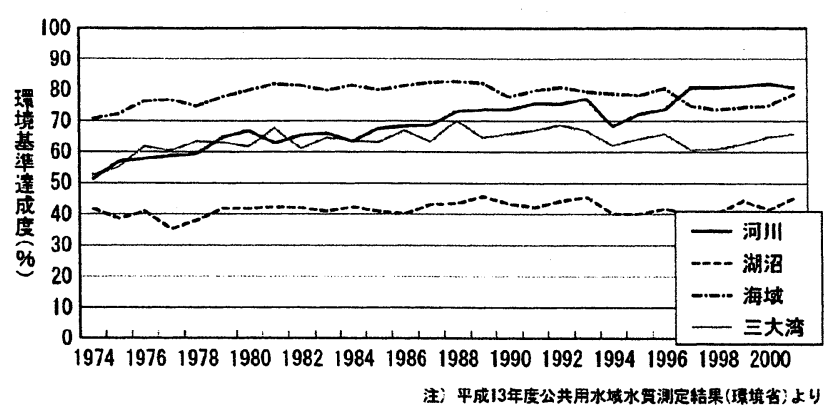

図-17 水域の水質の変化（環境省公共用水域水質 測定結果より作成)

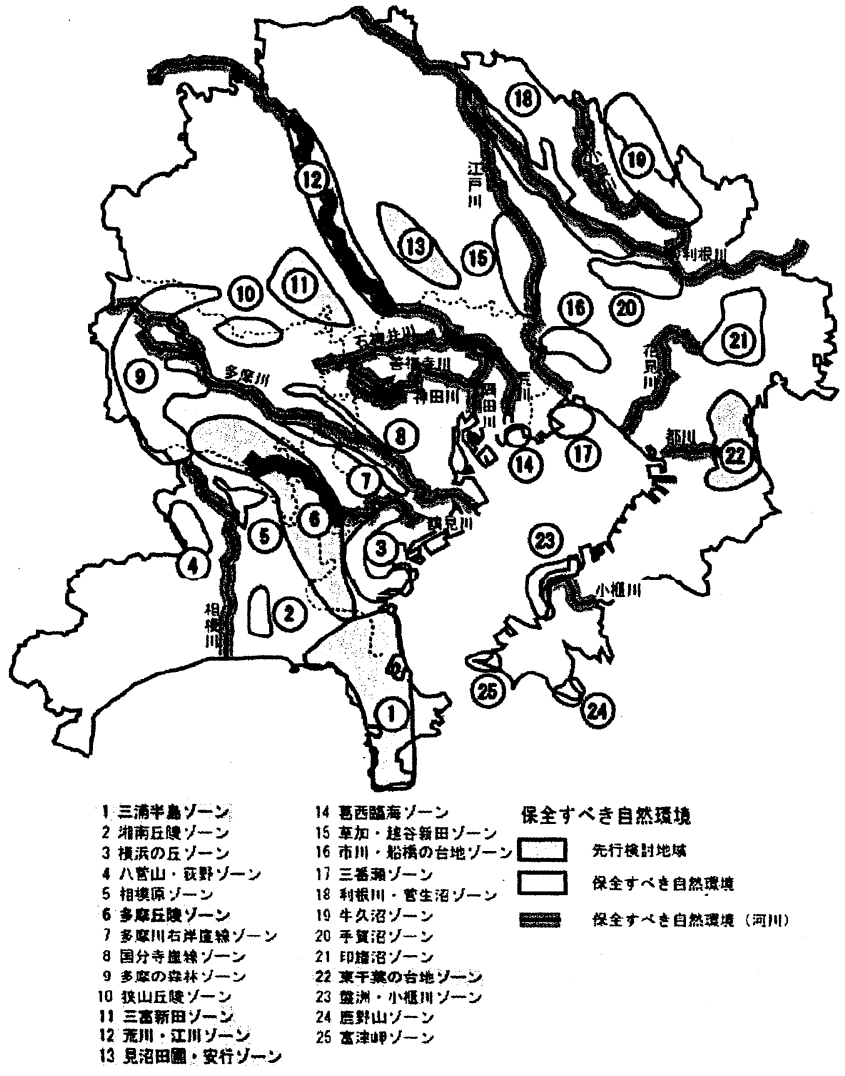

図-18 首都圏の環境インフラの保全計画 ${ }^{16)}$

これらの取り組みのほとんどでは、総合的な取り 組みが指向されているが、流域圈・都市再生の対象 などから、以下の 4 つに視点から分類できる（その 再生活動の内容加ら、一部は重複)。各分類について、 その内容と実際の代表的な事例との関わりを含めて 記すと以下のようである。

\section{(1)再生の対象からの分類}

流域圈·都市再生の対象としては、水·物質循環、 生態系・生物多様性、都市空間、経済、歴史や文化 の再興などがあり、それらと人々の暮らしや経済活 動との係わりにまで及ぶものがある。これらのうち の主要なものとして以下のようなものがある。 (1)水・物質循環の改善への取り組み
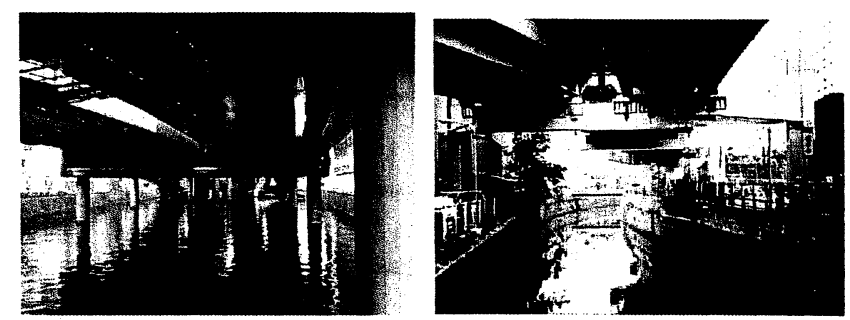

写真-1 高速道路に上空を覆われた都市河川 （左：日本橋川、右：渋谷川）

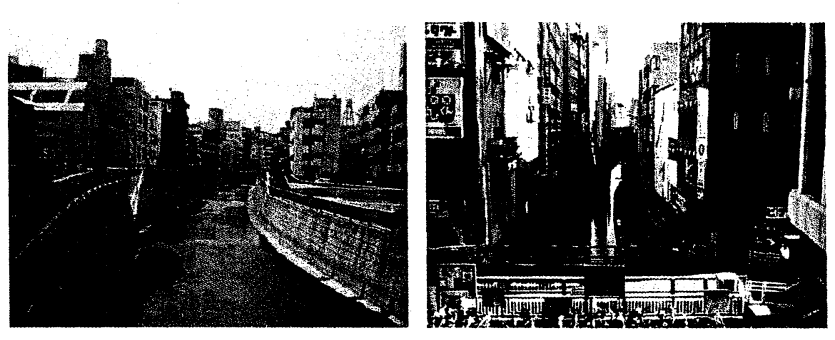

写真-2 深く掘り込まれた都市河川

（左 : 神田川、右 : 渋谷川)

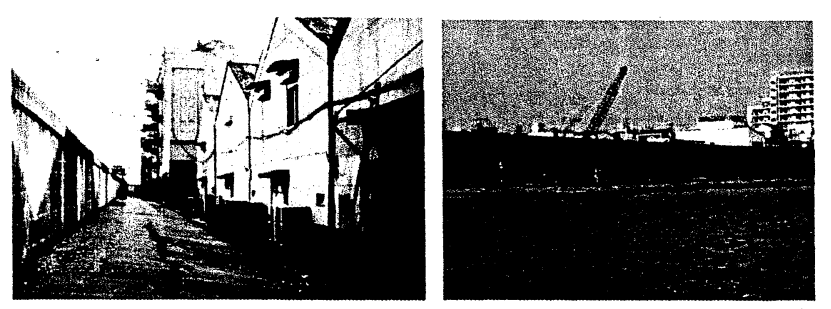

写真-3 堤防で分断されたまちと川（隅田川）

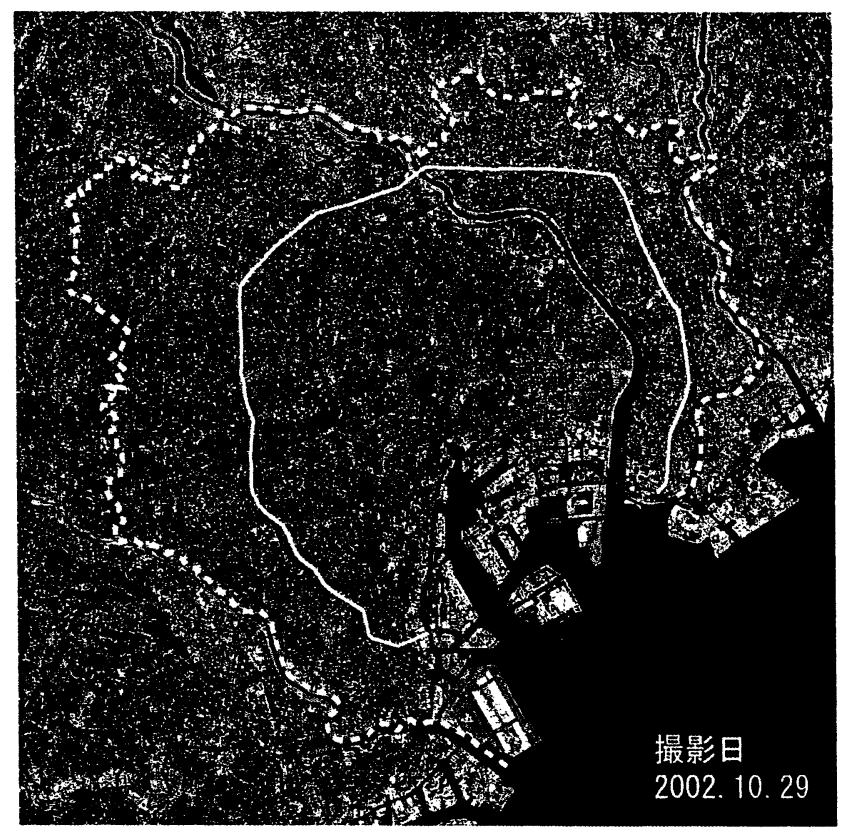

写真-4 東京の水域と緑の現状（Terra Astar）

これまでの取り組みの中では、河川や湾域の水質 改善を目指した、水・物質循環の改善に関するもの が最も多く、また実績がある。すなわち、河川や湾 域、湖沼の普段の水質改善（物質循環）に係わるも 
のとしては東京湾流入河川および湾の水質改善（水 質規制・総量規制）、マージ川流域再生 ${ }^{21}$, 8), 18), 19)、 チェサピーク湾再生 て),8,17)、ボストン湾の水質改善 7),8)などが、流域の水循環（普段の水量と洪水時の水 量) と水質に係わるものとしては印旛沼流域再生(水 循環健全化）77,8)が、洪水時の水循環に係わるものと しては中川・綾瀬川流域（総合治水）9などが挙げ られる。この他にも、国際河川であるライン川での 水質改善への取り組み ${ }^{8)}$ な゙がある。

(2)生態系再生への取り組み

生態系の保全と再生に関するものは、比較的近年 になってから取り組みが多くなった。この事例とし ては、マージ川流域再生 (どこでも魚が棲める川に) 7),8),18),19)、チェサピーク湾再生（天然種の牡蠣の保 全・再生） 7),8),17)、ライン川の再生（カムバック・ リーモン）て，15)などが挙げられる。

(3)緑の保全と再生

都市における緑の保全・再生とそれをもとにした 都市の成長管理に関しては、都市計画の分野では 20 世紀を通じての長い取り組みの経過がある。すなわ ち、20世紀初頭から緑の計画 (パークシステム、グ リーンベルトなど）がなされ、ある範囲でそれが現 在にも引き継がれている ${ }^{19)}$ 。そして、近年の日本の 事例としては、首都圏の環境インフラ（水と緑）の 保全・再生計画（図-18）があり、その取り組みが 進められつつある ${ }^{16)}$ 。

(4)河川空間の再生

都市における河川空間の再生とそれを核とした都 市再生への取り組みもなされるようになっている。 この事例としては、国内における東京・隅田川、北 九州・紫川、徳島・新町川での取り組みなどがあり、 海外では韓国の清渓川（平面道路・高架高速道路の 撤去と河川再生、清流の創出)、シンガポールのシン ガポール川（河川の水質改善、川沿いの地域の再開 発)、中国・上海の黄浦江の河岸再生（堤防上での幅 広い遊歩道の整備)、中国・上海の蘇州江の再生 (埋 められた川の再生、河畔の再開発、舟運の再生）な ど、世界的にも急激に進められるようになり、注目 されている (写真-5〜9) 17)。

\section{(2) 流域圈·都市のスケールからの分類}

上記の流域圈・都市再生の対象とともに、対象と する流域圈のスケールも重要である。

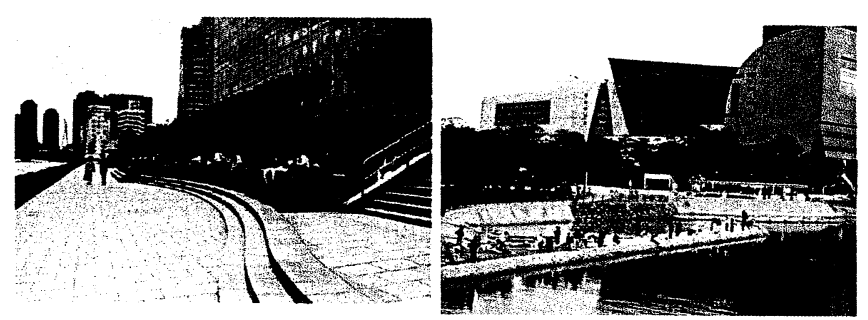

写真-5 都市における水辺の再生（左 : 東京 - 隅田 川、右 : 北九州、紫川)

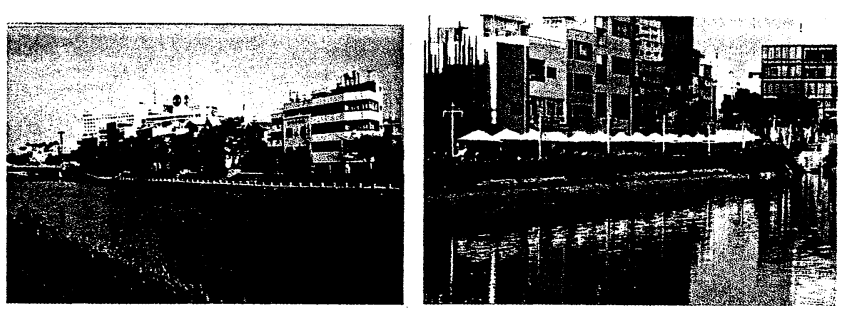

写真-6 徳島・新町川の再生

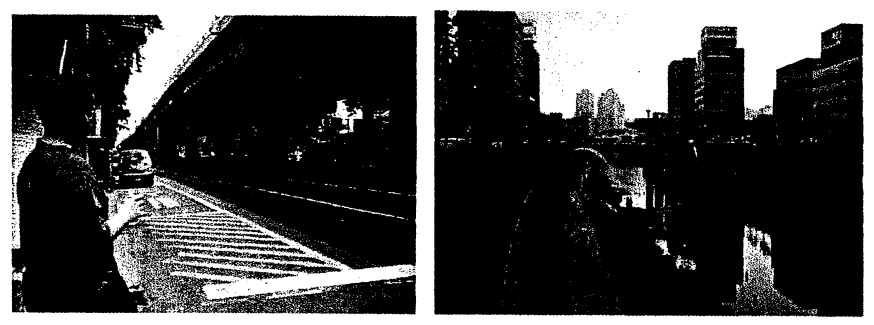

写真-7 韓国・ソウルの清渓川の再生 (左 : 再生前、 右 : 再生後)

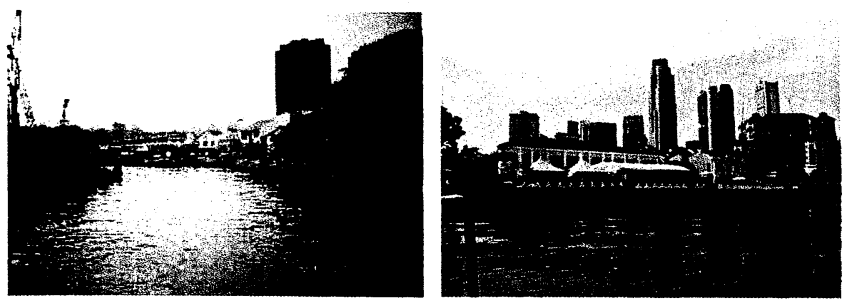

写真-8 シンガポールのシンガポール川とその周 辺の再生（左 : 再生前、右 : 再生後）

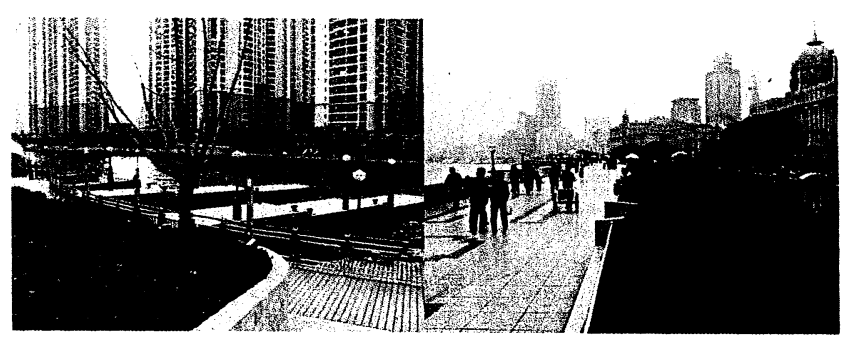

写真-9 中国 ·上海の蘇州河 · 黄浦江とその周辺の 再生（左：蘇州河、右 : 黄浦江）

\section{(1)大きな流域圈}

マージ川流域再生、チェサピーク湾再生（同湾と その流域)、東京湾再生（同湾とその流域）、ライン 川再生 (国際河川での水質、生態系、水循環の再生) などでの取り組みが挙げられる 77,8).15),177).18)。 
表一2 自然と共生する流域圈・都市再生に係わる実践事例とその概要

\begin{tabular}{|c|c|c|c|c|c|c|c|c|}
\hline & $\begin{array}{l}\text { マージ川流域キャンペ } \\
\text { ーン(英国) }\end{array}$ & $\begin{array}{l}\text { チェサヒーーク㴮流域再生 } \\
\text { (米国) }\end{array}$ & $\begin{array}{l}\text { カリフォルニア・ベイデルタ } \\
\text { 流域再生 (米国) }\end{array}$ & 地見川流域再生 & ボストン湾（港）流域再生 (米国) & 臼旗沼流域再生 & 洞海溥再生 & 東京潈流域再生 \\
\hline 概要 & 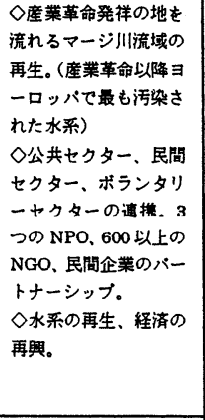 & 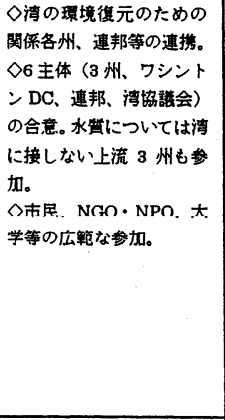 & 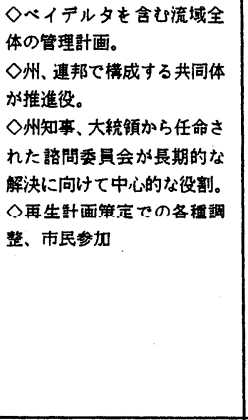 & 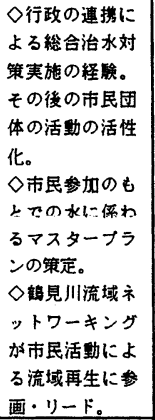 & 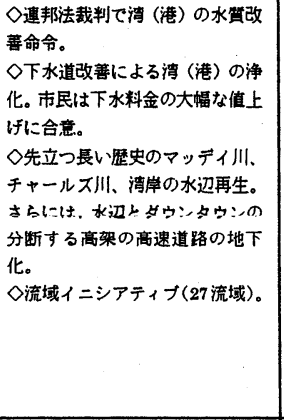 & 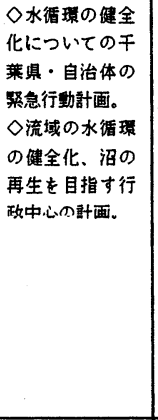 & $\begin{array}{l}\text { ○死の海と化 } \\
\text { していた海を } \\
\text { 民問企業の協 } \\
\text { カて再生。 }\end{array}$ & 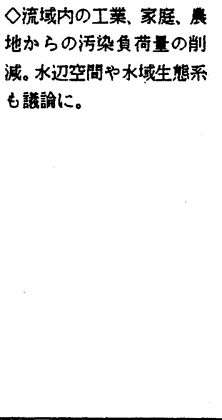 \\
\hline $\begin{array}{l}\text { 主な 再 } \\
\text { 生活動 }\end{array}$ & 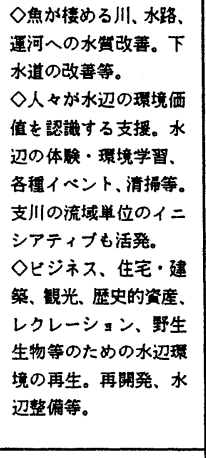 & 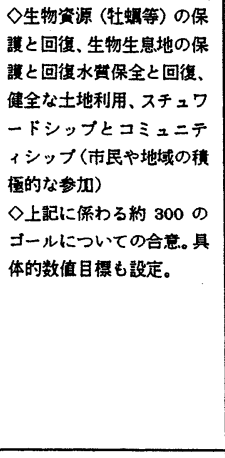 & 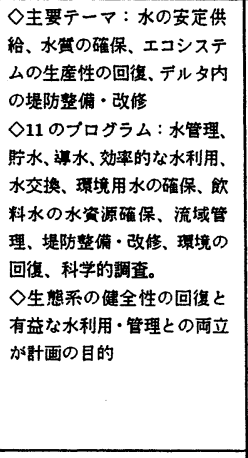 & 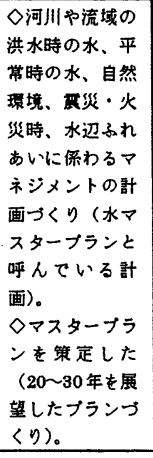 & 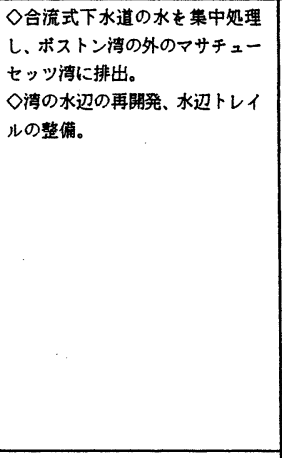 & $\begin{array}{l}\text { ○流入河川や沼 } \\
\text { の水蟹を改善す } \\
\text { るための多数の } \\
\text { 対策メニューを } \\
\text { 設定。 } \\
\text { ○当面およひ長 } \\
\text { 期の連成目儤の } \\
\text { 設定。 }\end{array}$ & $\begin{array}{l}\text { ○工場加らの } \\
\text { 排水の規制、 } \\
\text { 下水道整備、 } \\
\text { 底泥の棌湶。 } \\
\text { ○最近は生物 } \\
\text { を用いた浄 } \\
\text { 化。 }\end{array}$ & 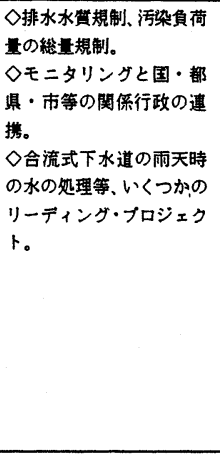 \\
\hline その他 & 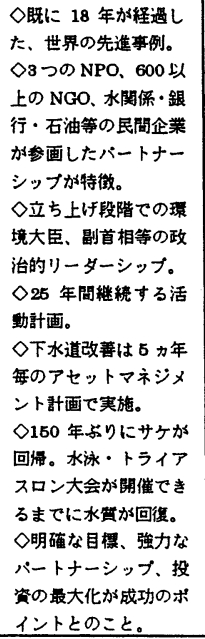 & 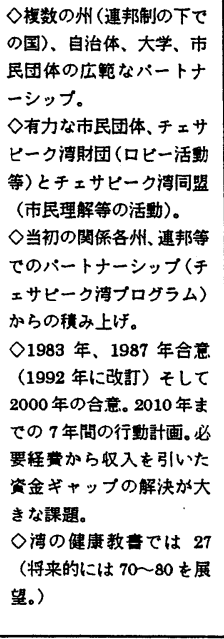 & 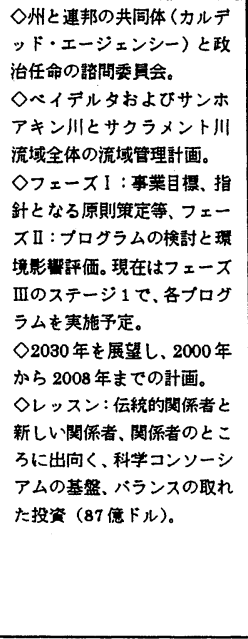 & 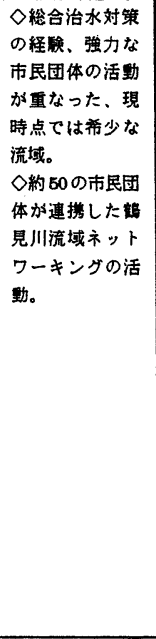 & 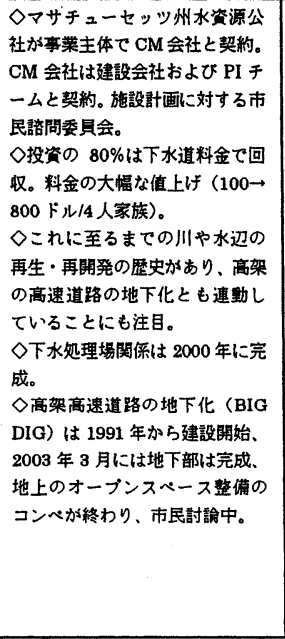 & 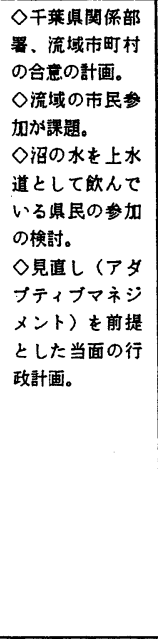 & $\begin{array}{l}\text { ○日本の殖産 } \\
\text { 興業、重厚長 } \\
\text { 大産業の発祥 } \\
\text { の地。最も早 } \\
\text { くから污染さ } \\
\text { れた水域の再 } \\
\text { 生事例。 } \\
\text { ○大企業の工 } \\
\text { 場等の特定污 } \\
\text { 染源。企業の } \\
\text { 㙝力・参加。 }\end{array}$ & 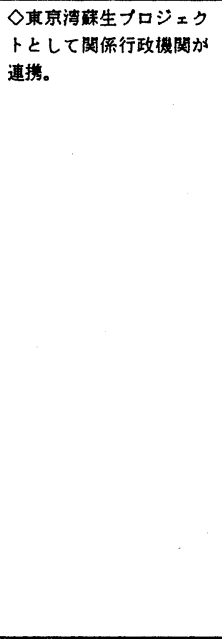 \\
\hline
\end{tabular}

(2)中規模、小規模な流域圏

鶴見川流域再生、印旛沼とその流域の水循環の健 全化、シンガポールのシンガポール川流域の再生、 中国・上海の䔡州河の再生、中川・綾瀬川流域やバ ンコク首都圏庁での総合治水対策などが挙げられる 7),8),9),17)。

(3河川とその周辺の再生

韓国・ソウルの清渓川の再生、シンガポール川と その周辺の都市再生 (川と河畔再生)、中国・上海の 蘇州川と黄浦江と河畔の都市再生、北九州の紫川と 河畔の都市再生、さらには名古屋の堀川、徳島の新 町川、東京の隅田川などでの取り組みが挙げられる 17)。これらは、都市における空間としての河川の再
生とともに、それを活かした都市の再生を目指した ものである。

\section{（3）再生シナリオの設定方法による分類}

再生シナリオの設定方法については、大別して以 下のように分類される。

(1) 概念シナリオ

地球温暖化への対応に関して想定された社会シナ リオ (SERES シナリオ)、あるいはローマクラブの成 長の限界で設定された社会シナリオなどのように、 現状の延長社会とそれを変更しようとする社会を示 すいくつかのシナリオを設定し、問題点や利点等を 分析し、明確に示すためのものである ${ }^{2), 5) 。 い わ ゆ ~}$ る科学的、技術的な検討で多く用いられている概念 
シナリオである。

このような再生シナリオは問題点等を分析し、あ るいは問題点を基本的な面で分かりやすく示す場合 などには用いられるが、実践に直結する再生シナリ オとはなりづらい。上述の実践事例には、このよう な概念シナリオを設定している事例はない。

(2)実践的シナリオ

これは、問題点や課題を分析して因果関係を明ら かにし、それを解決あるいは再生する上での制約や 課題を認識しつつ、現状を改善する高めの目標を設 定して、その目標に近づけるための対応すべき目標 （ゴール、対応）とするものである。このタイプの 流域圏・都市再生シナリオでは、多数のゴールある いは対応を設定するもの（チェサピーク湾再生 7),8),17)、印旛沼流域再生など 7),8)）と、集約した目標 あるいは行動規範を設定しているもの（鶴見川流域 再生 7),8，12)、マージ川流域再生 7),8，15)，17，18，19)、韓国・ ソウルの清渓川再生など 7),8),17)） がある。前者のチ エサピーク湾・流域の再生では約 300 の目標（ゴー ル）を設定し、印旛沼・流域の再生では、約 60 の対 态を設定している。後者のマージ川流域再生では、 固定的な目標は社会の状況の変化とともに問題が生 じること、あるいは新たな参加を制約すること等か ら、いくつかの行動基準と包括的な目標（どこでも 魚が生息できるようにする、水辺の価值を高める等) を設定して行動を行うこととしている。このため、 同流域では、計画ではなく流域キャンペーンとして

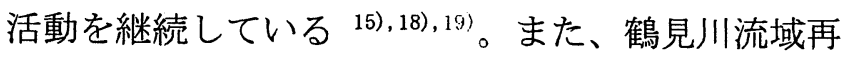
生では、水循環の再生、流域の生態系の保全・再生、 自然との係わりの再生など、集約した $5 つ$ 目標(マ ネジメントの対象）を設定している ${ }^{81,12)}$ 。韓国・ソ ウルの清渓川再生では、自然と人に優しい社会とす る、歴史を踏まえた再生などを大きな目標として設 定している7),17)。

そのような取り組みを経て、近年では、生態系、 生物多様性の保全・再生が目標に加えられるように なってきた。そしてさらに、都市における河川空間 や湾岸域等の水辺空間の再生とそれを核とした都 市・地域の再生、活性化が進められるようになって きた。

このように、自然と共生する流域圈・都市の再生 についての実践事例では、そのいずれにおいてもこ
表-3 再生シナリオの分類 （対象、スケール、設定方法による分類）

\begin{tabular}{|c|c|c|c|c|}
\hline & 小流域 (サブ流域) & 中㐬域 & 大流域 & 被数流域 \\
\hline 水物買循環 & $\begin{array}{c}\text { ○雨水眝留瀑透 } \\
\text { 汿水の復元 }\end{array}$ & 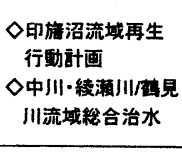 & & 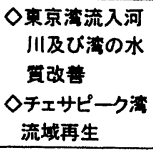 \\
\hline $\begin{array}{l}\text { 生態系(水城· } \\
\text { 陸坡)・緑 }\end{array}$ & 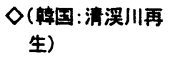 & & & \\
\hline 都市空成 & 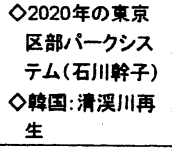 & 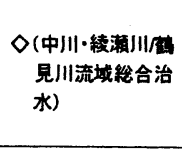 & & $\begin{array}{c}\text { ○首都圈の都市 } \\
\text { 環境インフラ } \\
\text { の㨹来像 }\end{array}$ \\
\hline 複合. 総合 & & $\begin{array}{l}\text { ○蕰見川水マスター } \\
\text { プラン }\end{array}$ & $\begin{array}{c}\text { ○マージ川流域 } \\
\text { キャンペーン }\end{array}$ & \\
\hline
\end{tabular}

の実践的シナリオを設定している。

以上のことを概念的に分類して例示したものが表 -3である。

\section{6. 流域圏·都市再生シナリオの設計、提示}

自然と共生する流域圈・都市再生シナリオとして、 先進的な事例の分析 - 考察等から、以下の 4 つのモ デル・シナリオを設計、提示したい。各モデル・シ ナリオの内容と実際の代表的な事例との関わりにつ いて記すと以下のようである。

\section{(1)単一流域モデル その1:複合目的シナリオ}

これは、マージ川流域キャンペーシ 7),8),18),19)や鶴 見川流域水マスタープラン 8),12)に見られるように、 (1)水・物質循環（普段の水循環、洪水時の水循環、 そして水質) の再生、(2)生態系・生物多様性の保全 · 再生、(3)河川とその流域空間の再生、(4)その他（鶴 見川における水と緑とのふれあいの再生、マージ川 における水辺の価值の向上、人々の意識の向上など） を複合的に目標とした再生活動である。鶴見川流域 での再生シナリオの対象と内容を示したものが図 -19 である。また、マージ川流域再生における行動 原則と活動一の参加組織等を示したものが図-20 で ある 19)。国際河川であるライン川流域再生 15)では、 水質の改善、生態系の回復、そして洪水を主として 対象とした水循環の再生（中流域での洪水を貯留、 遊水機能の回復）が目標として順次追加され、取り 組まれてきている。

\section{(2)単一流域モデル その2:単一目的シナリオ}

これは、日本における鶴見川流域や中川・綾瀬川 
における総合治水対策9)という洪水時の水循環系の 保全と健全化、印旛沼流域の水循環健全化 7).8)、洞 海湾（北九州）の再生 ${ }^{8}$ など、またアメリカのボス トン湾の水質改善 7),88などに見られるように、単一 流域で主として水・物質循環の再生を目標としたも のが想定される。アメリカの水質保全や、日本にお ける湖沼水質保全、流域下水道総合整備などは、単 一の目標を設定して広く行われてきた再生シナリオ での行動である。

今後は、単一流域の取り組みでは、このような単 一目的に加えて、河川やその流域内、さらには下流 に位置する湖沼の生態系の保全と再生を目標として 加えたものも多くなると推察される。

\section{（3）複数流域モデル:複合目的シナリオ、単一目的シ}

\section{ナリオ}

これは、複数の流域の下流域に位置する湾の再生 を目指すようなもので、複合目的シナリオとしては チェサピーク湾の再生（天然種の牡蠣の保全・再生 をシンボルとしつつ、(1)水・物質循環改善、(2)生態 系の保全・復元）のようなものが想定される 7),8),17)。 また、東京湾蘇生計画のように、湾の水質改善 (水・ 物質循環）というほぼ単一の目標を目指したものも 想定される 16)。

\section{(4)河川区間モデル:河川からの都市再生シナリオ}

これは、日本では 1980 年代から、そしてアジアで は近年急激に取り組みが進められるようになった河 川の再生と、それを核とした周辺の都市再生への取 り組みシナリオである。日本の隅田川 (東京)、紫川 (北九州)、新町川（徳島）、道頓堀川（大阪）での 川と河畔の都市再生、韓国・ソウルの清渓川とその 周辺の再生、中国・上海の蘇州河や黄浦江とその周 辺再生、中国・北京の高梁河とその周辺の再生、シ ンガポールのシンガポール川とその周辺の都市再生 7),18)にみられるようなものが想定される。都市河川 の空間とその周辺を含む沿川空間に着目した再生シ ナリオである。

都市の中での河川空間の位置づけとしては、日本 では帝都復興計画、東京緑地計画、防空計画、戦災 復興計画、そして第一次首都圈整備計画一と引き継

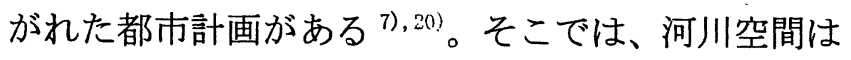
都市の重要な空間として構想・計画されていた。そ の現代的な再生を、上述の韓国・ソウルでの清渓川

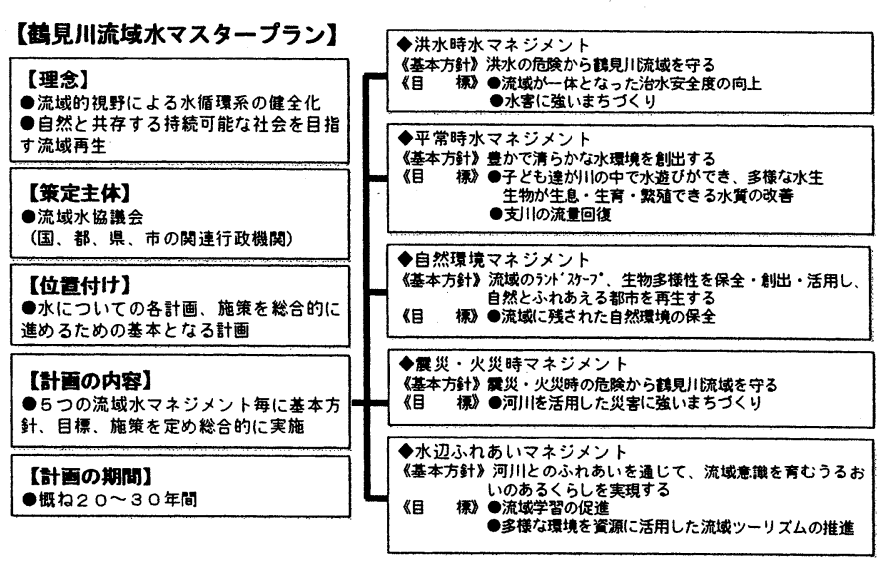

図-19 鶴見川流域の再生シナリオ（「鶴見川流域水 マスタープラン」より作成)

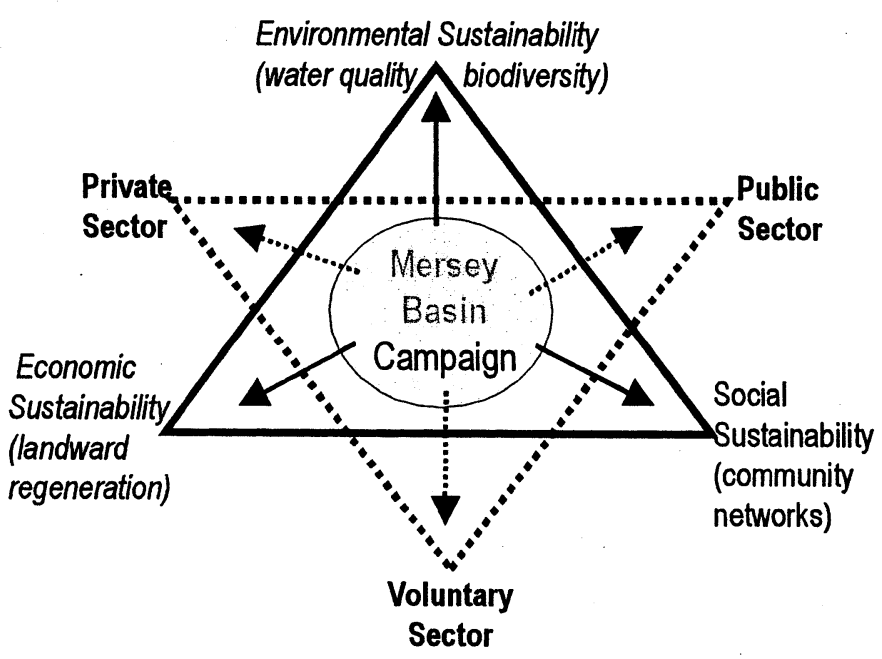

図-20 マージ川流域キャンペーンの行動原則と参 加組織等 (M. Turner) ${ }^{18), 19)}$

と都市の再生の実践事例 7,17に見ることができる。

自然と共生した流域圈・都市再生シナリオとして、 いくつかのバリエーションや複合タイプのものはあ り得るが、基本的な実践シナリオとしてはこれら 4 つのものが想定される。

\section{おわりに}

本論文では、自然と共生する流域圈・都市再生シ ナリオに関して以下のことを明らかにした。

(1)従来の研究を概観するとともに、実践的な流域 圈・都市再生に関する研究の必要性を述べた。

(2)日本の近年の人口の増加と都市化が環境に与えた 影響を水・物質循環と生態系（水と緑）の観点か ら概観した。

(3)自然と共生する流域圈・都市の再生、形成を議論 する上で、流域圏の形態を分析するとともに、本 
論文で取り扱いを明確にした。

(4)日本を含む世界の流域圈・都市の再生に係わる実 践事例について、流域圈の形態・スケールとの係 わり、再生・形成目標（1)水・物質循環、(2)生態 系・生物多様性、(3)河川空間など) から分析する とともに、それらを考慮して自然と共生する流域 圈・都市再生シナリオのモデルを提示した。

(5)以上の成果は、今後の自然と共生する流域圈・都 市再生について検討する上で参考とされ、実践に つなげられてよいと考える。

(6また、現在人口が急増し、都市化が急激に進展し ているアジア等の国々において、自然と共生する 流域圏・都市の形成の検討においても、本研究が 貢献し得ると考えられる。

なお、自然と共生した流域圏・都市再生シナリオ の研究に関しては、先述した総合科学技術会議が重 点研究課題として設定し、その推進を支援してきた 研究にも注目したい。第 2 期の科学技術基本計画に 引き続き、第 3 期の科学技術基本計画でも、自然と 共生する流域圈・都市の形成、再生に関するシナリ オの設計が重点テーマとなっている。第 3 期科学技 術基本計画においては、第 2 期計画では自然共生型 流域圏・都市再生の基本的要素の一つであった生態 系・生物多様性に関する研究が重点研究として独立 したが、自然と共生する流域圈・都市の再生、形成 シナリオの設計では、(1)水・物質循環とともに、(2) 生態系・生物多様性が基本コンポーネントであるこ とには変わりがない。本論文で述べた各再生シナリ オのモデルにおいても、水・物質循環および生態系・ 生物多様性が基本的なコンポーネントして含まれる。

\section{【参考文献】}

1）内閣府総合科学技術会議 :『自然共生流域圈・都 市再生イニシャアティブ報告書』, 内閣府総合科 学技術会議, 2005

2）内閣府総合科学李術会議:『地球温暖化研究最前 線』, 内閣府総合科学技術会議, 2002

3）加藤文昭・丹治三則・盛岡通 :「流域圈における シナリオ設計システムの構築に関する研究」, 環 境システム研究論文集, Vol. 32, pp. 391-402, 2004
4）丹治三則・盛岡通・藤田壮 : 流域圏でのシナリ 才誘導型の施策立案と評価を支援する地理情報 システムに関する研究, 環境システム研究論文 集, Vol.31, pp. 367-377, 2003

5）ドネラ H. メドウズ :『成長の限界一ローマ・ク ラブ 人類の危機レポート』, ダイヤモンド社, 1972

6）カール・スタイニッツ（矢野桂司訳）:『地理情 報システムによる生物多様性と景観プラニン グ』, 地人書房, 1999

7）吉川勝秀:『河川流域環境学』, 技報堂出版, 2005

8）石川幹子・岸由二・吉川勝秀編著 :『流域圈プラ ンニングの時代』, 技報堂出版, 2005

9）吉川勝秀・本永良樹 : 低平地緩流河川流域の治 水に関する事後評価的研究, 水文・水資源学会 論文集, 第 19 巻 4 号, pp. 267-pp. 279, 2006.7

10）丹保憲仁-円山俊朗編:『水文循環と地域水代謝』, 技報堂, 2003

11）岸由二 : 流域とはなにか,『流域環境の保全』, pp. 70-77, 朝倉書店, 2002

12）鶴見川流域水協議会:『鶴見川流域水マスタープ ラン』，国土交通省京浜河川事務，2004

13）国土庁:『第三次全国総合開発計画（三全総，閣 議決定)』, 1977

14）国土庁:『21 世紀の国土のグランドデザインー地 域の自立の促進と美しい国土の創造一（五全 総)』, 1998

15）田中栄治・谷口博昭編著 :『地域連携がまち・く にを変える』, 小学館, 1998

16）自然環境の総点検等に関する協議会 : 首都圏の 都市環境インフラのグランドデザイン, 2004

17）リバーフロント整備センター（吉川勝秀編著）: 『川からの都市再生一世界の先進事例から一』, 技報堂出版，2005

18）吉川勝秀：イギリスの「マージ川流域キャンペ ーン」について, 河川, No. 612, pp. 60-63, 1997.7

19）アーク・タナー：「流域連携によるマージ川流域 を例とした流域再生」, RIVER FRONT（リバーフ ロント整備センター)，第 53 号, 2005.5

20）石川幹子 :『都市と緑地一新しい都市環境の創造 に向けて一』, 岩波書店, 2001 
Study on the Scenario for Urban/Watershed Regeneration in Accord with Nature

\author{
Katsuhide YOSHIKAWA
}

In Japan, whose population has increased rapidly in recent about 100 years, but will decrease in future, it is demanded to aim at sustainable development in accord with nature restoring the water and material circulation, eco-system and landscape once lost in the basin/watershed scale. This study shows the necessity of regeneration scenario for the basin/watershed arranging the way to recognize them. It also analyses the progress/practical cases and plans in Japan and abroad based on their form/scale and purpose, and shows the model of the scenario for the urban/watershed regeneration in accord with nature taking those conditions into consideration. 